\title{
The Wattled-Wall House of Salar People and Its Conservation and Development
}

\author{
Mingjing Zhu ${ }^{1}\left(\mathbb{B}\right.$, Binsheng Luo $^{2}$, Ben La ${ }^{1}$, Ruijie Chen ${ }^{1}$, Fenggui Liu ${ }^{1, *}$ and Chunlin Long ${ }^{3,4, *(\mathbb{C})}$ \\ 1 College of Geography Sciences, Qinghai Normal University, Xining 810007, China; \\ zmj8964@aliyun.com (M.Z.); qhlaben@126.com (B.L.); rjchen@outlook.com (R.C.) \\ 2 Lushan Botanical Garden, Jiangxi Province and Chinese Academy of Sciences, Lushan 332900, China; \\ luobins@lsbg.cn \\ 3 Key Laboratory of Ecology and Environment in Minority Areas, National Ethnic Affairs Commission \\ (Minzu University of China), Beijing 100081, China \\ 4 College of Life and Environment Sciences, Minzu University of China, Beijing 100081, China \\ * Correspondence: liufenggui@igsnrr.ac.cn (F.L.); long@mail.kib.ac.cn (C.L.)
}

check for updates

Citation: Zhu, M.; Luo, B.; La, B.; Chen, R.; Liu, F.; Long, C. The Wattled-Wall House of Salar People and Its Conservation and Development. Sustainability 2022, 14 , 23. https://doi.org/10.3390/ su14010023

Academic Editor: Leonardo Becchetti

Received: 1 December 2021

Accepted: 17 December 2021

Published: 21 December 2021

Publisher's Note: MDPI stays neutral with regard to jurisdictional claims in published maps and institutional affiliations.

Copyright: (C) 2021 by the authors. Licensee MDPI, Basel, Switzerland. This article is an open access article distributed under the terms and conditions of the Creative Commons Attribution (CC BY) license (https:// creativecommons.org/licenses/by/ $4.0 /)$.

\begin{abstract}
Salar people are Turkic-speaking Islamic people and an ethnic group with a small population in China. Wattled-wall house of Salar people is a type of traditional house threatened by extinction. In 2008, the wattled-wall house construction skills were selected for the national intangible cultural heritage list. It is mainly distributed in Xunhua Salar Autonomous County, Qinghai Province of China. So far, Salar people's traditional wattled-wall house knowledge has been poorly documented. Therefore, a study supporting cultural preservation efforts is needed, including preserving plants used in its construction. This study mainly applied ethnobotanical methods based on data collection through observation, interviews, and documentation. Additionally, ArcGIS data analysis is also used to supplement the evaluation of the traditional wattled-wall house. This study aimed to (1) document traditional knowledge about the wattled-wall house construction, (2) and evaluate the current status of the wattled-wall house from different angles like the environmental adaptability and internal advantages and disadvantages. The result showed that the local people still apply the knowledge about the wattled-wall house from generation to generation. However, due to some practical reasons, the wattled-wall house is on the verge of extinction. There are 11 plant taxa used as construction materials in wattled-wall house. Conservation efforts for species involved in the wattled-wall house are needed, especially the ones with limited availability. Re-use of wattled-wall house is needed in order to maximize the economic benefits and to safeguard its historical and architectural values. It is recommended that the conservation of this cultural heritage needs more attention and effort from the local government or the society.
\end{abstract}

Keywords: wattled-wall house; traditional construction; the Salar people; ethnobotany; traditional knowledge

\section{Introduction}

Traditional houses are one of the most important artifacts of a society's historical life [1]. However, variation in the design and construction of houses depends on the available construction material and the prevailing environmental conditions [2,3]. In a traditional agricultural society, limited by the level of construction industry and the transportation capacity, local materials for traditional buildings have always been utilized according to their natural properties. Moreover, other factors such as geographical locations, climate, natural environment, and other social factors to satisfy basic functional requirements are also considered during construction $[4,5]$. In some areas, traditional houses are proven to be coherent and sustainable to the environment and the people [6,7].

The traditional architectural form reflects various regional and cultural characters [8,9]. Most traditional dwellings rely mostly on the supply of suitable wood, plant, soil, and stone 
for basic components such as load-bearing posts, roof supports, walls, doors, etc. [10,11] However, the diversity of plant species used as a building material are rarely reported. A previous study on Salar ethnic groups in Northwest China reported that local architectures are unique and well adapted to the local environment [12,13].

Salar people are Turkic-speaking Islamic people and an ethnic group with a small population in China [13]. Salar people live primarily in Xunhua Salar Autonomous County, Qinghai Province, Northwest China. The wattled-wall house is the typical traditional local dwelling in the Salar community, which has existed for more than 500 years. It is now on the verge of extinction due to the fast development of the rural economy and the weak awareness about the construction culture of the Salar people.

As they live on the Qinghai-Tibet plateau, Salar traditional house, also known as the wattled-wall house, are seen as an adaptation to the natural environment. Xunhua County is near Mengda national natural reserve, where the local environment provides Salar communities with inexhaustible basic building materials such as plants, silt, wood, and store. In the Salar region, lumber is readily available, and thus houses are built of wood and surrounded by an earthen wall courtyard. Wattled-wall houses are composed of the main room, kitchen, guest room, and stable. However, the traditional wattled-wall house faces challenges in maintaining the building elements' sustainable concept, form, and antiquity due to the development of the rural economy, the change of the natural environment, and the loss of construction skills. The old generations of Salar people formed a unique aesthetic in their long understanding of the environment and put this philosophy into the wattled-wall house. However, new generations' ignorance about Salar architecture culture's value would lower community efforts to preserve the cultural heritage.

To understand how the Salar people build the traditional wattled-wall house and what plant natural materials they use, we (1) provide a description of the wattled-wall house, as well as its building techniques and distribution; (2) identify the diversity of plant species used for construction; (3) simulate the spatial distribution of the wattled-wall house; and (4) finally, discuss the future of the development of wattled-wall house construction skills, as well as its protection and inheritance.

\section{Materials and Methods}

\subsection{Study Area}

Xunhua Salar Autonomous County is located in the eastern Qinghai-Tibet Plateau, is characterized by many steep mountains, and is known for its widespread home garden and rich indigenous knowledge. The geographic location is between $102^{\circ} 1^{\prime} \mathrm{E}-102^{\circ} 7^{\prime} \mathrm{E}$ and $35^{\circ} 4^{\prime} \mathrm{N}-35^{\circ} 8^{\prime} \mathrm{N}$. (Figure 1). It is approximately $90 \mathrm{~km}$ long and $40 \mathrm{~km}$ wide. The total area is about 2100 square kilometers, and it is about $150 \mathrm{~km}$ far from Xining, the provincial capital city of Qinghai Province. The mean annual temperature and rainfall of the Salar are about $8.5^{\circ} \mathrm{C}$ and $264.4 \mathrm{~mm}$, respectively. The area is characterized by ecological and cultural richness, in conjunction with high levels of both poverty and malnutrition. Compared with other mountains, river valleys and grassland areas of the Mengda region have abundant rainfall and a warm climate and are therefore suitable for growing plants. Its forest coverage rate is higher than other areas of Qinghai province. The unique and high plant diversity provide the plant-sourced building materials for house construction. The Mengda national natural reserve, which most Salar communities inhabit, is adjacent to the Yellow River Bay, relying on the stone mountain range in a shallow and hilly area. The ground gradually rises from near the water surface and is connected to the mountain range. Compared with other areas in Xunhua County, less slopy land is suitable for building houses. It is also an important reason for promoting the development of the wattled-wall house to the two floors. 


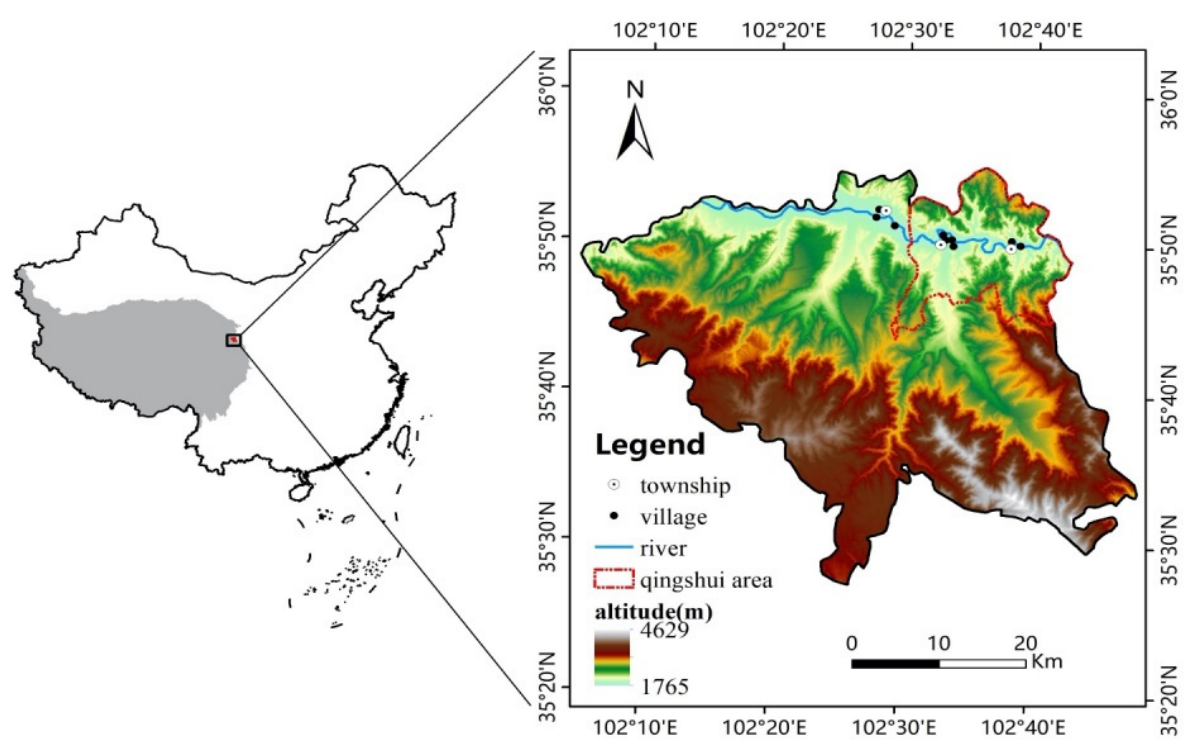

Figure 1. The geographic location of the study area.

\subsection{The Ethnobotanical Methods}

Various approaches such as informal conversations, observations around homesteads, field excursions, and semi-structured interviews were used to collect the informations. Inheritors of the wattled-wall house were consulted at the beginning of the study and took their verbal consent for our work. The chiefs were regularly informed about the project's progress and were again consulted in September 2020 to obtain their agreement to publish the results. Herbarium vouchers were collected in the Mengda national natural reserve.

Every homestead with a wattled-wall house is one sample. There are six homesteads with existing wattled-wall houses that we investigated for about $3-4 \mathrm{~h}$ each. The study gathered indigenous knowledge on wattled-wall houses and plant species of construction material in and around the Mengda national natural reserve. The selection of informants and key informants was based on information obtained from inheritor and religious leaders. During interviews, we asked questions like, "Are there people who have more knowledge about the wattled-wall house?" or "How do you know if someone is more knowledgeable about the wattled-wall house?" and "How did you collect building materials? "and" How did you build the wattled-wall house?". In Salar's culture, construction is considered a male activity. Our observations and records cover local wisdom, botany, plant use, traditional house construction, social culture, and traditions. This gendered distribution led us to conduct the first open-ended interviews with Salar elder men of built wattled-wall house skills.

After identifying reliable informants in preliminary open-ended interviews, each category of plant species of each house was numbered. Each informant was interviewed separately to limit the influence of the other people's presence. Additional data such as the description of construction techniques were collected in semi-structured interviews between September 2020 to March 2021, on three field trips carried out in each study site, followed by guided field walk, discussions, and observation, with informants and key informants.

Ethnobotanical walks were undertaken in the surrounding forest with three local Salar people to identify the species corresponding to each folk name of material previously identified as used in the houses. The local names of the species and their uses were crosschecked to ensure consensus. Herbarium vouchers, photographs, and GPS coordinates were collected for each plant or species. 


\section{Results}

\subsection{The Characteristics of the Wattled-Wall House}

The traditional residences of the Salar people were nurtured and developed under the influence of Central Asian Turkic culture, Islamic culture, ethnic cultures, and multiple backgrounds. These houses are well adapted to natural conditions with complex terrain and diverse climatic characteristics. The traditional construction skills of the wattled-wall house have been included in the Chinese National Intangible Cultural Heritage since 2008. The skilled craftsmen of the Salar people have carved the Central Plains, Tibetan, and Islamic cultures on the walls, doors, windows, stairs, and railings of the wattled-wall house in the form of engravings with their superb carving skills, adding to the beauty of the wattled-wall house. The carving decoration of the house is mainly on the second floor (Figure 2). Normally, the wattled-wall house is two floors; the ground floor is for livestock or as a storage room, and the second floor is used as a hall and for meeting guests. In the houses, water rooms are generally designed to facilitate worship. The walls are ventilated and reduce the weight of the house, rarely for load-bearing. So, the wall material chooses the branches and weaves them into a fence. Yellowish-brown is the primary color of the building materials of the wattled-wall house, blending with the environment. In terms of color, Salar people like to be elegant and simple. Coupled with the restrictions of religious beliefs and local materials, they did not use strong colors in their houses. Construction materials of floor and roof are generally wooden board.

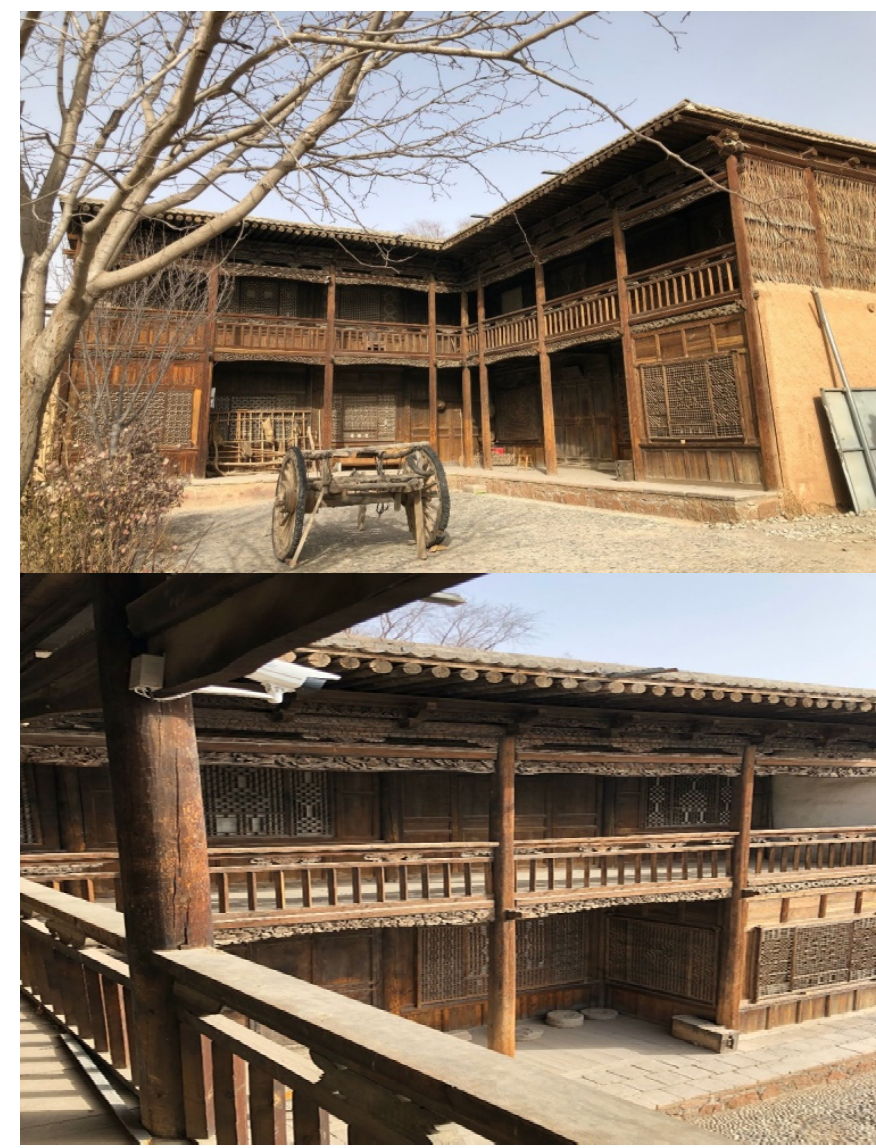

Figure 2. The wattled-wall house.

The forest coverage rate is high around Salar communities, providing local houses with rich natural building materials. According to the statics, more than 500 species, including Picea crassifolia, Pinaceae, Swida alba, Lonicera webbiana, and other hardy forest trees, are used for construction (Figure 3). Swida alba and Lonicera webbiana are the main materials for making wattled-wall because of their nearby availability. We noticed that the wattled-wall 
house is also a symbol and a benchmark for the perfection of life for the people. Apart from being a historical legacy of ancestral civilization, the wattled-wall house has also played an important role in living and carrying out various daily activities. In terms of local wisdom, the wattled-wall house reflects the intellectuality of the local community in utilizing and managing the biological resources of the plants around them.

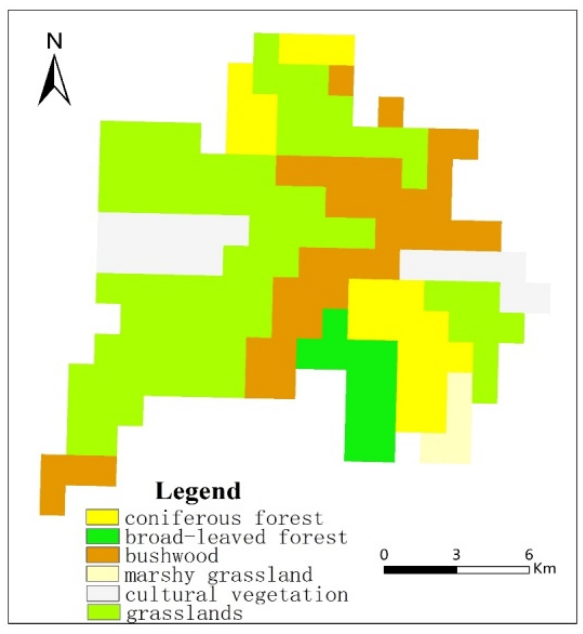

Figure 3. Vegetation type of Qingshui Township.

\subsection{Distribution of the Wattled-Wall House}

The birthplace and main distribution area of wattled-wall houses are in Da Zhuang Village, Hanping Village, Tashapo Village, Muchang Village, and Suotong Village in Qingshui Township (Figure 1). However, the current wattled-wall house settlement only exists in Qingshui township.

Architecture researchers pointed out that the construction of the wattled-wall house is based on human beings in a specific geographical environment, to take advantage of the favorable conditions provided by the local nature such as temperature, precipitation, distance from the river, and vegetation types, combined with their own national culture [14]. Smart houses adapt to the regional natural environment and the social and cultural environment [15]. Therefore, we assumed that there would be the distribution of wattled-wall house without considering social and economic status as long as there is a population distribution area. Under this assumption, the spatial distribution of the wattled-wall house in the ideal state mentioned above can be calculated based on the population density spatial distribution map of Qingshui Township, combined with the average number of residents in the wattled-wall house.

We used the 2020 population density data released by WorldPop [16] and intercepted the population density data of Qingshui Township through ArcGIS. The unit is person/100 square meters, as shown in Figure 4. According to the research of related architecture scholars, the number of people living in most fence buildings is three to five people. The author uses four people as the basis for calculation and obtains the number distribution of fence buildings per 100 square meters under the author's assumptions. (Figure 5) According to the statistical results, under the author's hypothesis, the total number of wattled-wall house in Qingshui Township is about 2680. 




Figure 4. The spatial distribution of population density in Qingshui Township.

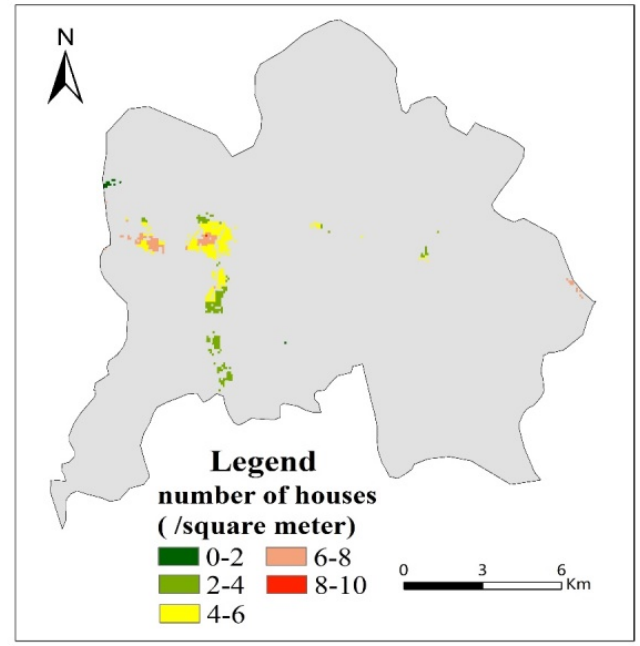

Figure 5. Distribution of number of wattled-wall houses per 100 square meters.

According to the study result, as originally a smart residence adapted to the local geographical environment, the current number of wattled-wall house is very different from the number simulated by us, which indicates that some factors have seriously accelerated the disappearance of the wattled-wall house. Because of the fast development of the rural economy and the continuous emergence of new building forms and materials, the traditional houses have been gradually replaced by new-style houses. Many wattledwall houses are built along the Yellow River. With the impact of climate change and the impoundment of nearby hydropower stations, the water level rises, causing some houses to be submerged or demolished. Additionally, Salar people lack awareness and understanding of the local cultural heritage. The younger generation of Salar people has not realized the cultural importance and the advantages of the traditional wattled-wall house.

\subsection{Construction of Wattled-Wall}

The overall construction of the traditional wattled-wall house is made of natural materials and built with traditional techniques without metal, and its concept leads to energy saving. Salar people believe that using wood as pegs can make the wattled-wall house more solid and durable; adversely, nails or metal in buildings can cause corrosion, leading to damage to the wattled-wall house construction. The layout of the wattled-wall house is based on considerations about safety, security, and comfort. The house itself complies with all four principles, including using less harmful materials, energy saving, good-quality materials, and eco-friendly materials. According to the interview, during the construction of the wattled-wall house, the family heads (usually male) provided 
$77.5 \%$ of labor, followed by other household members $(15.1 \%)$, neighbors $(6.2 \%)$, and hired labor $(1.2 \%)$. The women do not usually get involved in actual house construction but occasionally collect grass and water.

The utilization of local natural materials could effectively reduce the cost of energyconsumption and transportation. There are two main forms of weaving fences: one is the original weaving form, in which holes are drilled on the side of the column, and the fence is braided directly on the frame; the other one is the optimization method, which is currently more commonly used and has a prefabricated structure, weaving the fence and wall. Wattled-wall house has smooth air circulation, and the temperature inside is stable because air can circulate through the gaps of the reeds. Walls made with plant branches can also help to adjust to the environment's temperature. With good air circulation and a stable room temperature, foodstuffs are not prone to spoilage, and animal attacks can be avoided.

\subsection{Plant Species Used and Processed during the Construction}

Construction of wattled-wall houses is done using raw materials from plant species that grow around local communities. Some construction plant uses are well known, probably across large parts of China, particularly those concerning large hardwoods used for construction houses and furniture $[17,18]$. There are six species of trees and five species of climbers used to construct wattled-wall houses (Table 1). Before the construction, local people usually arrange the wood in sequence and dry it in sunlight until small fine crack lines appear.

Table 1. Plant species used for wattled-wall house.

\begin{tabular}{|c|c|c|c|c|c|}
\hline No. & Name & Family & Chinese Name & Use Part & Features \\
\hline 1 & Swida alba & Cornaceae & $\begin{array}{c}\text { 红瑞木 } \\
\text { hongruimu }\end{array}$ & Wall (Stem) & Resilient \\
\hline 2 & $\begin{array}{l}\text { Lonicera } \\
\text { webbiana }\end{array}$ & Caprifoliaceae & $\begin{array}{c}\text { 华西忍冬 } \\
\text { huaxirendong }\end{array}$ & Wall (Stem) & Resilient \\
\hline 3 & $\begin{array}{l}\text { Quercus } \\
\text { mongolica }\end{array}$ & Fagaceae & $\begin{array}{c}\text { 辽东栋 } \\
\text { liaodongli }\end{array}$ & Wall (Stem) & Resilient \\
\hline 4 & $\begin{array}{l}\text { Viburnum } \\
\text { betulifolium }\end{array}$ & Adoxaceae & $\begin{array}{c}\text { 桦叶荚 } \\
\text { huayejiami }\end{array}$ & Wall (Stem) & Resilient \\
\hline 5 & $\begin{array}{c}\text { Betula } \\
\text { platyphylla }\end{array}$ & Betulaceae & 白桦 biahua & Wall (Stem) & Straight \\
\hline 6 & Ulmus pumila & Ulmaceae & 白榆 baiyu & Wall (Stem) & Straight \\
\hline 7 & $\begin{array}{l}\text { Lindera } \\
\text { umbellate }\end{array}$ & Lauraceae & $\begin{array}{c}\text { 大叶钓樟 } \\
\text { dayediaozhang }\end{array}$ & Wall (Steam) & Resilient \\
\hline 8 & $\begin{array}{l}\text { Populus } \\
\text { davidiana }\end{array}$ & Salicaceae & 山杨 shanyang & $\begin{array}{l}\text { Wall, Door, } \\
\text { Window } \\
\text { (Steam) }\end{array}$ & Straight \\
\hline 9 & $\begin{array}{c}\text { Picea } \\
\text { crassifolia }\end{array}$ & Pinaceae & $\begin{array}{c}\text { 青海云杉 } \\
\text { qinghaiyunshan }\end{array}$ & $\begin{array}{l}\text { Beam, Door, } \\
\text { Window } \\
\text { (Branches) }\end{array}$ & Straight \\
\hline 10 & $\begin{array}{c}\text { Cyclobalanopsis } \\
\text { glauca }\end{array}$ & Fageceae & 青冈 qinggang & $\begin{array}{c}\text { Beam } \\
\text { (Branches) }\end{array}$ & Straight \\
\hline 11 & $\begin{array}{l}\text { Pinus } \\
\text { armandii }\end{array}$ & Pinaceae & $\begin{array}{c}\text { 华山松 } \\
\text { huashansong }\end{array}$ & $\begin{array}{c}\text { Roof, Beam, } \\
\text { Window, } \\
\text { Door } \\
\text { (Branches) }\end{array}$ & Straight \\
\hline
\end{tabular}

\subsection{SWOT Analysis of Conservation and Inheritance of the Wattled-Wall House}

The main internal advantages and disadvantages, and external opportunities and threats related to the Salar wattled-wall house are arranged in a matrix form and then analyzed systematically (Table 2) [19]. 
Table 2. SWOT analysis of wattled-wall house.

\begin{tabular}{|c|c|c|c|}
\hline \multicolumn{4}{|c|}{ SWOT Analysis } \\
\hline Internal cause & $\begin{array}{l}\text { Strengths (S): } \\
\text { National Intangible } \\
\text { Cultural Heritage. } \\
\text { Unique national cultural } \\
\text { innovation. } \\
\text { Use local materials to save } \\
\text { energy. } \\
\text { Low cost and economical. } \\
\text { Weaknesses (W): } \\
\text { People's awareness of } \\
\text { protection and inheritance } \\
\text { is weak. } \\
\text { Lack of inheritors. }\end{array}$ & External cause & $\begin{array}{c}\text { Opportunities }(\mathrm{O}): \\
\text { China attaches great } \\
\text { importance to the cultural } \\
\text { protection of ethnic } \\
\text { minorities. } \\
\text { China attaches great } \\
\text { importance to the } \\
\text { protection of intangible } \\
\text { cultural heritage. } \\
\text { The state attaches great } \\
\text { importance to the } \\
\text { protection of traditional } \\
\text { villages. } \\
\text { Rural tourism } \\
\text { development. } \\
\text { Threats (T): } \\
\text { Modern urbanization } \\
\text { development impact; } \\
\text { the contradiction between } \\
\text { protection and } \\
\text { development; } \\
\text { Lack of relevant laws and } \\
\text { regulations }\end{array}$ \\
\hline
\end{tabular}

According to SWOT analysis, the trend of SO is greater than that of WT. Therefore, the protection of wattled-wall house construction skills still has important value, and it is the crystallization of the wisdom of the Salar people. As human intangible cultural heritage, it has the value of protection and inheritance and development and optimization.

\subsection{ArcGIS Data Extract and Analysis}

There are six well-preserved wattled-wall houses found in Dazhuang Village, Xunhua County. (Table 3) According to ArcGIS extraction of relevant data on the location of existing houses, it shows that the wattled-wall houses were built on the flat land of a river valley with a gentle slope, which was an easy area for human activities in ancient times. Being close to the water source is conducive to the development of agricultural activities. The fence building is about $1800 \mathrm{~m}$ above sea level. The altitude is not that high in the plateau region, which also helps the Salar ancestors adapt to the environment after moving in quickly.

Table 3. ArcGIS extraction data.

\begin{tabular}{ccccc}
\hline No. & $\mathbf{N}$ & $\mathbf{E}$ & Slop & Altitude (m) \\
\hline 1 & 35.83222 & 102.6394 & 10.01 & 1875 \\
2 & 35.8325 & 102.6394 & 11.93 & 1874 \\
3 & 35.83194 & 102.6386 & 8.74 & 1865 \\
4 & 35.83472 & 102.6394 & 3.18 & 1857 \\
5 & 35.83389 & 102.6403 & 9.09 & 1864 \\
6 & 35.83444 & 102.6403 & 5.88 & 1859 \\
\hline
\end{tabular}

According to relevant meteorological statistics, the average annual rainfall in Xunhua County is about $260 \mathrm{~mm}$, and the seasonal distribution is uneven. The rainy season is concentrated from June to August, accounting for $63.5 \%$ of the total annual rainfall. The temperature and rainfall are very beneficial to the growth of forests and pastures. The roof slope is gently designed to ensure that the roof is not easily washed by rain when it rains, and it is convenient to clean the snow when it snows to prevent the roof from leaking. The 
roof can also supplement the courtyard, dry food, dry vegetables, etc., and erect a wooden ladder to go up and down the roof.

The location of the wattled-wall house fully reflects the concept of harmony between nature and the environment. Because the Salar people pursue an ideal living environment, they will combine a series of natural and geographical environmental factors such as geographical location, topography and landforms, climatic conditions, and regional landscapes when building houses to create a good long-term living environment.

\subsection{Mordern Wattled-Wall House}

The architectural form of the wattled wall has strong recognition. By protecting and inheriting the characteristic architectural structure of the wattled-wall house, the purpose of promoting the Salar culture can be achieved, which can enhance its social and cultural value status and bring social and economic benefits, and eventually reach a virtuous development cycle. Therefore, the local government has adopted some practical and effective decisions to preserve the traditional style and features of the traditional wattled-wall house; promote the construction techniques and elements of traditional wattled-wall house to build the modern wattled-wall house; and use these houses to develop local tourist attractions, villages, and town residential areas. The modern wattled-wall house develops economic activities integrating food, leisure, accommodation, browsing, and culture, and expands the prospects for developing wattled-wall houses and their construction techniques.

Nowadays, the construction of the modern wattled-wall house does not entirely use traditional technology (Figure 6). In the face of the emergence of modern materials and new technologies, there is a need to find the inheritance route between modern and traditional techniques. Traditional houses are potential resources that, if rehabilitated or reused, can provide inexpensive and appropriate premises for commercial and community purposes. Accompanied by the rapid development of the urbanization economy, it has been impacted by modernization. Modern materials and modern residential buildings have strong adaptability, high substitutability, and high craftsmanship. Therefore, the traditional wattled-wall house and residential building techniques are gradually being replaced. Modern houses are acquired by developers and renovated for commercial purposes such as hotels, restaurants, private museums, and community purposes such as cultural centers.
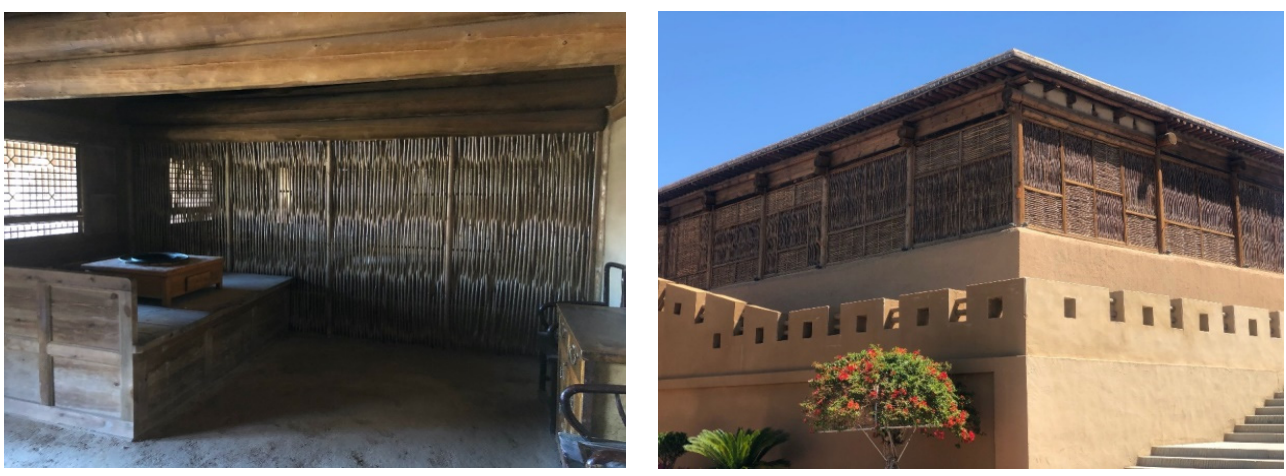

Figure 6. Modern wattled-wall house.

\section{Discussion}

\subsection{Challenges and New Poitioning of Traditional Wattled-Wall House}

The wattled-wall house is an iconic traditional architecture of Salar people. However, the traditional wattled-wall house faces the threat of demolition and disappearance. Some traditional wattled-wall houses re being demolished and rebuilt but in a more modern form. According to the survey, in 2017, the wattled-wall house has dropped sharply from more than 100 in the past to only 22 at present. According to our observation, the Salars have a low recognition degree of this intangible cultural heritage, especially the younger generation who is no longer interested in traditional wattled-wall houses. Instead, 
they prefer a modern lifestyle. In addition, the Salar communities are located in Mengda National Nature Reserve, where natural material gathering is illegal, leading to a very high cost of building, repair, and maintenances of the wattled-wall house. Comparatively, the functionality and comfort are not as good as modern houses. All these factors cause the Salar wattled-wall houses to be indispensable for local people.

From the aspect of the whole Salar history, the construction technique of the wattledwall house is an innovation of the ethnic architectural culture. It utilizes the climate characteristics and natural resources of the Mengda area and integrates the religious beliefs and the Salar aesthetic attributes. Therefore, we believe that the definition of the wattledwall house should no longer be residential, but as a cultural symbol documenting the historical development of the Salar ethnic group.

\subsection{The Ecological Value and Cultural Value of Wattled-Wall House}

Building is one of the most important fields to address energy saving, emission reduction, and climate change. Facing the challenge of climate change, the development of green buildings is very important $[20,21]$. Salar people used natural materials to build a highly regional, energy-saving, and environmentally friendly wattled-wall house. Therefore, the fence building is more in line with the modern green building development concept. The raw soil and stone used in construction of the wattled-wall house do not need to be roasted, which can save fuel. At the same time, these materials can also be reused, solving the problem of construction waste regeneration and giving full play to the performance characteristics of natural building materials. This not only causes no environmental pollution, but also reflects the construction wisdom of local people to protect and adapt to the local environment. In the background of the current resource-saving and environment-friendly society, the wattled-wall house has outstanding structural characteristics, which help the Salar people to find a balance between the abundant forest resources and the shortage of land resources. This on-site, economical, practical, and cost-saving construction method is also in line with the current concept of sustainable development.

The protection and inheritance of construction technology is conducive to the protection of the material cultural heritage of local buildings, and it is also conducive to the protection of intangible cultural heritage, that is, traditional construction technology. It can promote the sustainable inheritance of architectural heritage and protect traditional culture to a large extent. Traditional wattled-wall houses have important ecological, economic, and cultural values, as well as national symbolism. The construction technique of the wattled-wall house is an innovation of the national architectural culture. It uses the climate characteristics and natural resources of the Mengda area; integrates the religious beliefs and aesthetic attributes of the Salar people; and shows a solid, practical, and beautiful architectural cultural value. The wattled-wall house is simple in color, sturdy and durable, and is integrated with the surrounding natural environment, thus reflecting the religious and cultural characteristics of the Salars, advocating nature and returning to the original. Through the protection and inheritance of the characteristic architectural form of the fence building, the purpose of promoting the Salar culture can be achieved, and so its cultural value can be enhanced.

\subsection{The Protection and Future of Wattled-Wall House}

The protection and the inheritance of the wattled-wall house are meaningful and necessary. Thus, our suggestions are as follows:

Encourage local people to use the construction skills, construction components, and decorative elements of the wattled-wall house on the modern house. The traditional construction elements could not only improve the quality of the house but also help to maintain the local ethnic culture. The government and relevant cultural relics protection departments should adopt management measures and protection plans, give the people a considerable and actionable blueprint, and raise the people's recognition and attention from the ideological level, in order to inspire them to protect and develop wattled-wall houses. 
Incorporate the wattled-wall house into the development of the cultural tourism industry. The wattled-wall house can show tourists the real picture of local livelihood in the past. The characteristic ethnic culture, food, residential buildings, mosques, Mengda Nature Reserve, etc. owned by Salar people are all available development resources. Tourism resource evaluation, overall tourism positioning and development, and green tourism can be carried out through professional planning departments. The strategy and goals, planning priorities and steps, market positioning and marketing strategies, related supporting and service facilities, and investment benefit evaluation. Re-restoring the style and features of the wattled-wall house can enhance the cultural value of tourism. Pushing the architectural cultural landscape of the wattled-wall house to the market town area can enhance the value of the landscape. Additionally, it could increase the recognition of the ethnic culture for the Salar's young generation.

Salar people have their own language but no written language, and the stability of inheritance was poor. It is also possible to set up an eco-museum [22,23] by taking the complete traditional wattled-wall house building settlement as a specimen, an authentic and holistic way of protection. Eco-museum can develop economy, improve people's lives, protect heritage, and promote culture. The basic approach of eco-museum is to protect a target object with a complete ecological environment in situ. The specific goal is to protect the historical features and cultural characteristics of the environment and maintain the historical memory and cultural heritage of the wattled-wall house in order to sort out the master consciousness of the settlement residents [24,25].

Under current conditions where deforestation is a big problem, modern wattled-wall houses can be technically updated and functionally replaced on the basis of traditional fence buildings, for example, by replacing new biodegradable thermal insulation materials, using fence walls as prefabricated components to hang outside, striving to conform to traditional styles in appearance, and being compatible with innovation in internal design. Through continuous optimization, it provides suitable development methods for the traditional wattled-wall house in the contemporary social environment.

\section{Conclusions}

The cultural heritage conservation is essential to preserve the memory of monuments, places, and territories, and to ensure their transmission to the future. The traditional structures in China pay attention to the harmoniousness between humans and nature. So, the specific selection of construction materials in each area has various exhibitions at different geographical locations. Traditional wattled-wall house construction skills are a set of local unique construction systems formed by people through the accumulation of longterm experience. However, under the current rapid social development, traditional houses are facing disappearance and challenges. Through continuous optimization of construction skills and effective protection, suitable development methods can be provided for the fences of traditional Salar houses in the contemporary social environment department.

The construction of a wattled-wall house embodies the in-depth regional genes, outstanding regional and national characteristics, and the perfect combination of architecture and the natural environment. The wattled-wall materials are the most obvious geographical feature. The research on the traditional wattled-wall house of Salar people was performed to explore the indigenous construction techniques, cultures, and characteristics embodied in the buildings, and to provide efficient protection and inheritance. Moreover, the research helps to find new ways of expressing regional and national characteristics in constructing modern buildings in local and other settlements of Salar people.

Author Contributions: Conceptualization, C.L.; Formal analysis, M.Z. and B.L. (Binsheng Luo); Investigation, M.Z., B.L. (Ben La) and R.C.; Writing-original draft preparation, M.Z.; Writingreview and editing, B.L. (Binsheng Luo) and C.L.; Supervision, C.L. and F.L.; Project administration, C.L.; Funding acquisition, C.L. All authors have read and agreed to the published version of the manuscript. 
Funding: This research was funded by the National Nature Science Foundation of China (31761143001, 31870316), the Biodiversity Survey and Assessment Project of the Ministry of Ecology and Environment of China (2019HJ2096001006), the Science and Technology Department of Qinghai Province (2020-ZJ-750) and Minzu University of China (2020MDJC03).

Institutional Review Board Statement: Not applicable.

Informed Consent Statement: Informed consent was obtained from all subjects involved in the study.Written informed consent has been obtained from the patient(s) to publish this paper.

Data Availability Statement: Not applicable.

Acknowledgments: We are very grateful to the Salar people who provided valuable information, traditional knowledge and culture, and hospitality. We would like to thank all people who contributed to the development of this study.

Conflicts of Interest: The authors declare no conflict of interest.

\section{References}

1. Tai, H.X.; Yang, Y.L.; Shen, L. Analysis on Wall Material and Construction Technology of Traditional House in Yubei Village. Appl. Mech. Mater. 2012, 174-177, 187-190. [CrossRef]

2. Naïma, F.; Mébirika, B.; Belkacem, D.; Claude-Alain, R. The Traditional House with Horizontal Opening: A Trend towards Zero-energy House in the Hot, Dry Climates. Energy Procedia 2016, 96, 934-944. [CrossRef]

3. Picuno, P. Use of traditional material in farm buildings for a sustainable rural environment. Int. J. Sustain. Built Environ. 2016, 5, 451-460. [CrossRef]

4. $\quad$ Perez-Monserrat, E.M.; De Buergo, M.A.; Gomez-Heras, M.; Muriel, M.J.V.; Gonzalez, R.F. An urban geomonumental route focusing on the petrological and decay features of traditional building stones used in Madrid, Spain. Environ. Earth Sci. 2013, 69, 1071-1084. [CrossRef]

5. Ogeron, C.; Odonne, G.; Cristinoi, A.; Engel, J.; Grenand, P.; Beauchene, J.; Clair, B.; Davy, D. Palikur traditional roundwood construction in eastern French Guiana: Ethnobotanical and cultural perspectives. J. Ethnobiol. Ethnomed. 2018, 14, 28. [CrossRef]

6. Ma, K.; Liu, B.T. The Inheritance and Development for Wooden Roof of the Traditional House in Nyingchi, Tibet. Adv. Mater. Res. 2011, 255-260, 1489-1493. [CrossRef]

7. Pronk, A.; Mistur, M.; Li, Q.; Liu, X.; Blok, R.; Liu, R.; Wu, Y.; Luo, P.; Dong, Y. The 2017-18 design and construction of ice composite structures in Harbin. Structures 2019, 18, 117-127. [CrossRef]

8. Bertolin, C.; Loli, A. Sustainable interventions in historic buildings: A developing decision making tool. J. Cult. Herit. 2018, 34, 291-302. [CrossRef]

9. Ribera, F.; Nesticò, A.; Cucco, P.; Maselli, G. A multicriteria approach to identify the Highest and Best Use for historical buildings J. Cult. Herit. 2020, 41, 166-177. [CrossRef]

10. Yusran, Y.A.; Suryasari, N. Bolon and Lobo: Revealing the Stack Construction on Batak Simalungun and Kulawi Traditional House. Int. J. Eng. Technol. 2013, 8, 187. [CrossRef]

11. Obafemi, A.O.; Kurt, S. Environmental impacts of adobe as a building material: The north cyprus traditional building case. Case Stud. Constr. Mater. 2016, 4, 32-41. [CrossRef]

12. Kakudidi, E.K. A study of plant materials used for house construction around Kibale National Park, western Uganda. Afr. J. Ecol. 2007, 45, 22-27. [CrossRef]

13. Zhu, M.; Luo, B.; La, B.; Chen, R.; Liu, F.; Long, C. Homegarden agroecosystems managed by Salar people on Qinghai-Tibet Plateau. J. Ethnobiol. Ethnomed. 2021, 17, 1-12. [CrossRef] [PubMed]

14. Chiotinis, N. The request of sustainability and architecture as cultural paradigm. Manag. Environ. Qual. Int. J. 2006, 17, 593-598. [CrossRef]

15. Zhang, D.; Shah, N.; Papageorgiou, L.G. Efficient energy consumption and operation management in a smart building with microgrid. Energy Convers. Manag. 2013, 74, 209-222. [CrossRef]

16. Miranda, L.; Lima, C. On the logistic modeling and forecasting of evolutionary processes: Application to human population dynamics. Technol. Forecast. Soc. Chang. 2010, 77, 699-711. [CrossRef]

17. Berg, F.; Flyen, A.-C.; Godbolt, Å.L.; Broström, T. User-driven energy efficiency in historic buildings: A review. J. Cult. Herit. 2017, 28, 188-195. [CrossRef]

18. Gibson, L.; Watt, C. Acetic and formic acids emitted from wood samples and their effect on selected materials in museum environments. Corros. Sci. 2010, 52, 172-178. [CrossRef]

19. Igliński, B.; Skrzatek, M.; Kujawski, W.; Cichosz, M.; Buczkowski, R. SWOT analysis of renewable energy sector in Mazowieckie Voivodeship (Poland): Current progress, prospects and policy implications. Environ. Dev. Sustain. 2021, 1-35. [CrossRef]

20. Santamouris, M.; Cartalis, C.; Santamouris, M. Building Resilient Cities to Climate Change. In Future City Architecture for Optimal Living; Springer Optimization and Its Applications; Springer: New York, NY, USA, 2015; Volume 102, pp. 141-159. [CrossRef] 
21. Zhang, J.; Qin, X.D. The Importance of Building Energy-Saving Show from the Change of Climate Parameters in Energy-Saving Standards. Appl. Mech. Mater. 2014, 587-589, 397-400. [CrossRef]

22. Dogan, M. Ecomuseum, community museology, local distinctiveness, Hüsamettindere village, Bogatepe village, Turkey. J. Cult. Herit. Manag. Sustain. Dev. 2015, 5, 43-60. [CrossRef]

23. Corsane, G. Sustainable future scenarios for people, environments and landscapes in Cumbria: The ecomuseum ideal and issues related to its use. Int. J. Biodivers. Sci. Manag. 2006, 2, 218-222. [CrossRef]

24. Ganobjak, M.; Brunner, S.; Wernery, J. Aerogel materials for heritage buildings: Materials, properties and case studies. J. Cult. Herit. 2020, 42, 81-98. [CrossRef]

25. Gálvez, F.P.; de Hita, P.R.; Martín, M.O.; Conde, M.M.; Liñán, C.R. Sustainable restoration of traditional building systems in the historical centre of Sevilla (Spain). Energy Build. 2012, 62, 648-659. [CrossRef] 